\title{
Endoscopy in Pregnancy: A Systematic Review
}

\author{
Partha Pal ${ }^{1} \quad$ D. Nageshwar Reddy ${ }^{1} \quad$ Manu Tandan ${ }^{1}$ \\ ${ }^{1}$ Medical Gastroenterology, Asian Institute of Gastroenterology, \\ Hyderabad, Telangana, India

\begin{abstract}
Address for correspondence Partha Pal, MD, DNB, MRCP (UK), 6-3-661, Somajiguda, Hyderabad, Telangana 500082, India (e-mail: partha1986@yahoo.com).
\end{abstract} \\ Medical Gastroenterology, Asian Institute of Gastroenterology,
}

J Digest Endosc 2021;12:138-150.

\begin{abstract}
Keywords

- pregnancy

- esophagogastroduodenoscopy

- flexible sigmoidoscopy

- colonoscopy

- endoscopic retrograde cholangiopancreatography

- endoscopic ultrasound
\end{abstract}

Background Fetomaternal outcomes are of primary concern for gastrointestinal (GI) endoscopy in pregnancy. We aimed to systematically review the safety and utility of endoscopic procedures in pregnancy.

Methods A systematic literature search was performed using PubMed. All original research articles with sample size $>10$ involving endoscopy in pregnancy were included for the review along with case report/series describing novel/rare techniques from 1948 to July 2021.

Results After screening 12,197 references, 216 citations were found and finally 66 references were included. Esophagogastroduodenoscopy had favorable fetal outcome $(>95 \%)$ based on two large retrospective studies and a review of case reports. Sclerotherapy and band ligation of varices were safe according to case series. A large nationwide cohort study established safety of endotherapy for nonvariceal bleed. Botulinum toxin and pneumatic dilation in achalasia are only supported by case reports. Percutaneous endoscopic gastrostomy can be useful to support nutrition based on case reports. A retrospective case-control and cohort study with systemic review justified flexible sigmoidoscopy if strongly indicated. Low birth weight was more common when sigmoidoscopy was done in inflammatory bowel disease based on a prospective study. Colonoscopy was considered safe in second trimester based on a case-control study whereas it can be performed otherwise only in presence of strong indication like malignancy. Capsule endoscopy is promising and can be useful in acute small bowel bleeding although risk of capsule retention is unknown. There are no reports of enteroscopy in pregnancy. Twelve retrospective studies and one prospective study showed high success rate of therapeutic endoscopic retrograde cholangiopancreatography (ERCP) $(>90 \%)$ in all trimesters and can be performed if strongly indicated. Pregnancy was an independent risk factor for post-ERCP pancreatitis in a large nationwide case-control study. Radiation-free ERCP with wire-guided bile observation, stent-guided or precut sphincterotomy, endoscopic ultrasound (EUS) guidance, and spyscopy have been described. Safety of EUS is limited to case series and can be used in intermediate probability of choledocholithiasis to guide ERCP and endoscopic cystogastrostomy.

Conclusion This review concludes that Gl endoscopy during pregnancy can be done effectively if strongly indicated with good fetomaternal outcomes. Precautions are advocated during procedures where radiation exposure is expected.
DOI https://doi.org/

10.1055s-0041-1739567

ISSN 0976-5042 (c) 2021. Society of Gastrointestinal Endoscopy of India.

This is an open access article published by Thieme under the terms of the Creative Commons Attribution-NonDerivative-NonCommercial-License, permitting copying and reproduction so long as the original work is given appropriate credit. Contents may not be used for commercial purposes, or adapted, remixed, transformed or built upon. (https://creativecommons.org/licenses/by-nc-nd/4.0/).

Thieme Medical and Scientific Publishers Pvt. Ltd. A-12, 2nd Floor, Sector 2, Noida-201301 UP, India 


\section{Introduction}

Endoscopy plays a crucial role in managing gastrointestinal (GI) disorders in general population and is considered safe. However, this could not be extrapolated to pregnant women requiring $\mathrm{GI}$ endoscopy due to scarcity of robust clinical data and concern regarding fetomaternal complications. Risk factors unique to endoscopy in pregnancy include risk of teratogenicity/premature labor with anesthetic medications, placental abruption or fetal injury with deep intestinal intubation, radiation during endoscopic retrograde cholangiopancreatography (ERCP), and maternal intraprocedure complications like hypotension/hypertension, hypoxia, and arrhythmia. ${ }^{1}$

The literature regarding endoscopy in pregnancy is limited to various small isolated case reports/series, and few retrospective studies although recently few prospective studies and nationwide cohort studies with population control have been reported. ${ }^{2-5}$ Guidelines are limited and outdated. ${ }^{5}$ It is difficult for the busy practicing gastroenterologist to find and judge clinical data for endoscopy in pregnancy in the absence of prospective, controlled studies which are scarce due to difficulty and reluctance in research due to concern for fetal safety and medico-legal implications. ${ }^{1}$ Moreover, the implications of various endoscopic procedures (esophagogastroduodenoscopy [EGD], sigmoidoscopy, colonoscopy, ERCP, endoscopic ultrasound [EUS], etc.) may vary according to various trimesters of pregnancy. For this reason, our review attempts to address the clinical need of the practicing gastroenterologists contemplating endoscopy in pregnancy. It would be a ready reckoner for all endoscopic procedures including sedation in pregnancy based on latest available data so that endoscopists can take informed decisions, modify procedural techniques, and counsel their patients regarding possible risk and benefits. This will also stimulate clinical research in this unattended area by identifying loopholes of currently available data. ${ }^{1}$

\section{Search Strategy}

References for this review were identified through searches of PubMed from 1948 until July 2021 using search terms "(Pregnancy) and (endoscopy)." A total of 12,197 citations were screened by one reviewer. A total of 216 relevant citations were identified. Separate searches were done with keywords like (sedation), (esophagogastroduodenoscopy: EGD), (sclerotherapy), (endoscopic variceal banding), (flexible sigmoidoscopy), (colonoscopy), (endoscopic retrograde cholangiopancreatography: ERCP), (enteroscopy), (capsule endoscopy), (endoscopic ultrasound: EUS), (endoscopic cystogastrostomy), (radiation-free ERCP), (endoscopic spyscopy), and (pregnancy). Important cross-references from selected citations were included. Papers describing endoscopy postpartum or with small sample size $(n<10)$ were excluded unless describing novel/rare techniques. A total of 66 references are included in the review ( - Fig. 1).

\section{Anesthesia during Endoscopy in Pregnancy}

Anesthetic agents during pregnancy can be subdivided into narcotics (meperidine, fentanyl, propofol), sedatives (diazepam and midazolam), general anesthetics (ketamine), and reversal agents (naloxone, flumazenil) or according to the Food and Drug Administration (FDA) pregnancy category

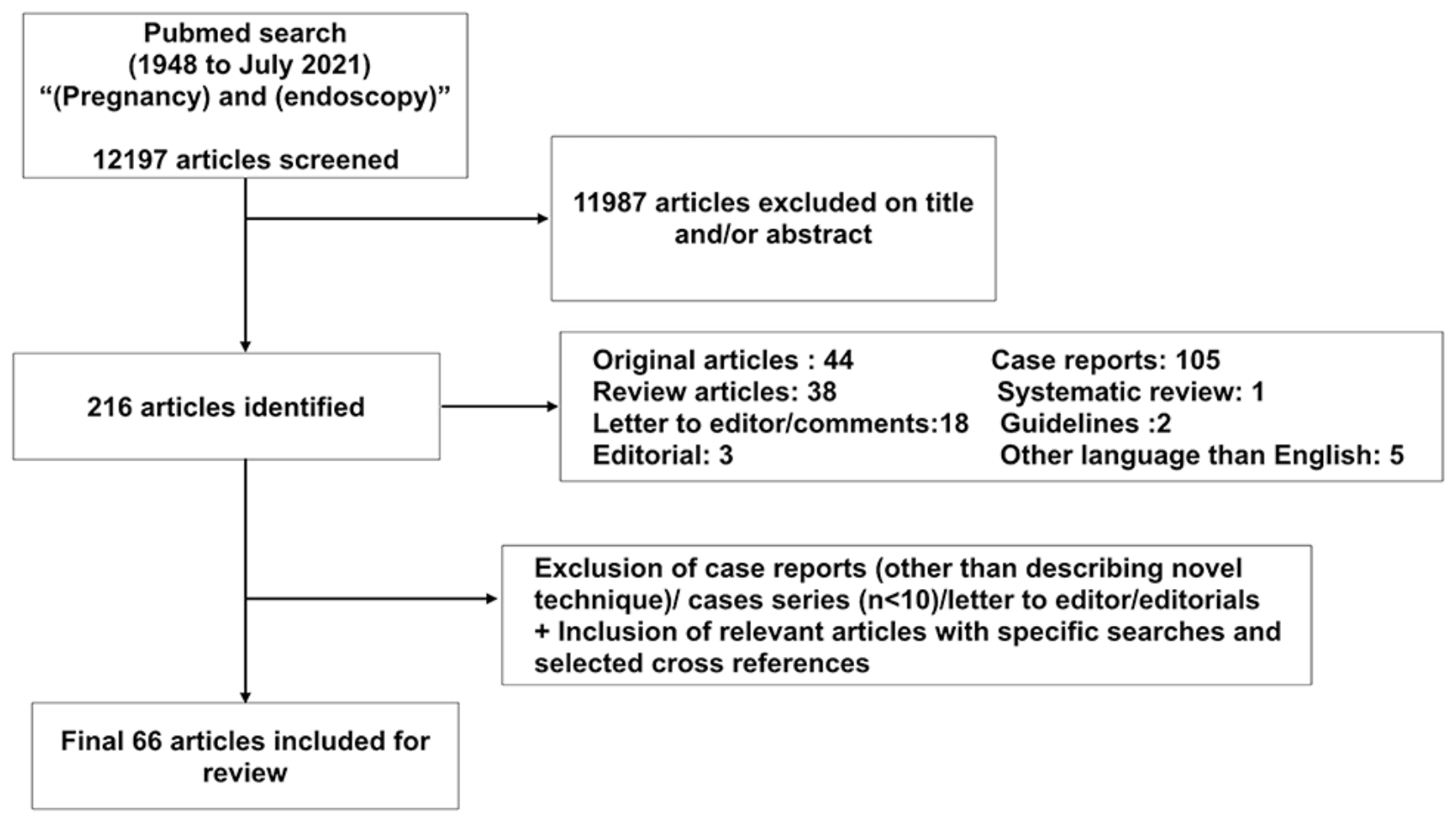

Fig. 1 Search strategy for systematic review on endoscopy in pregnancy. 
(category A: none; category B: propofol, ketamine, naloxone; category C: fentanyl, flumazenil; category D: diazepam, midazolam, high dose, prolonged meperidine at term; category $\mathrm{X}$ : none) ${ }^{1}$

Prolonged administration ( $>36$ hours) of meperidine can cause respiratory depression and seizures. Hence, other safer opioid alternatives like fentanyl (FDA C) with faster onset and offset of action is used more frequently.

Propofol is increasingly being used in general population for sedation during endoscopy. Ketamine is an alternative in cases where propofol is expected to be inadequate. Both agents are short acting with rapid recovery although the safety has not been studied in first trimester. Propofol has narrow therapeutic index and can cause respiratory depression, arrest, and even death if improperly monitored. Prolonged, high dose of ketamine is unsafe in pregnancy. ${ }^{1,6}$

Among sedatives, diazepam is a category D drug due to possible association with cleft lip, mental retardation, cardiac anomalies, and neurological defect (e.g., Mobius syndrome). Midazolam is preferred over diazepam as it is not associated with cleft lip. However, its use should be restricted specially in first trimester. ${ }^{1,6}$

Naloxone is indicated for narcotic toxicity but can precipitate opioid withdrawal in dependent patients. Due to a report of fetal death, its use should be restricted in pregnancy. Flumazenil for benzodiazepine overdose has limited safety data in pregnancy and hence benzodiazepines should be used in lowest dose with gradual titration. ${ }^{6}$

Informed consent, review of medical history, routine blood investigations, obstetric consultation, patient stabilization, deferring if possible to second trimester, secure intravenous line, and referral to expert endoscopist for high-risk procedures are prerequisites of endoscopy with anesthetics during pregnancy. ${ }^{6}$ Use of smallest effective dose of anesthetics, preferential use of category B drugs over C, minimization of procedure time (e.g., sigmoidoscopy instead of colonoscopy), oxygen supplementation, vitals, and electrocardiography monitoring with optional fetal cardiac monitoring are intraprocedural considerations. Fetal heart sounds should be documented before and after the procedure. At our institute, propofol under supervision of anesthesiologist is the drug of choice in all trimesters of pregnancy. ${ }^{1}$

\section{Esophagogastroduodenoscopy}

Diagnostic EGD in pregnancy should be performed if strongly indicated and going to change the therapy. Upper GI bleed causing hemodynamic instability, ongoing bleed, recent onset progressive dysphagia with weight loss, and suspected upper GI malignancy are strong indications for EGD with high diagnostic yield.

Studies on diagnostic EGD in pregnancy have been summarized in - Table $\mathbf{1 . 1} \mathbf{1}^{3,7,8}$ These studies indicate that the highest diagnostic yield of EGD is for upper GI bleeding (95\%) and lower for other indications (50-82\%). Reflux esophagitis was most common finding in diagnostic EGD whereas peptic ulcer disease (PUD) was less common as compared to the general population. The symptoms of PUD decrease with pregnancy and reflux symptoms increase. The frequency of Mallory-Weiss tear as a cause of upper GI bleed was similar to that of PUD (14\%). ${ }^{7}$ Intractable vomiting and hyperemesis gravidarum (HG) are other frequent indications for EGD in pregnant female. However, the diagnostic yield of EGD in intractable vomiting (69\%) was lower than upper GI bleeding (82\%) according to a study from Israel on 60 pregnant patients. $^{8}$ More importantly, EGD in case of intractable vomiting does not lead to major change in management as empirical use of proton pump inhibitors and $\mathrm{H} 2$ blockers can provide symptomatic relief. Bagis et al have found that Helicobacter pylori infection was more common in pregnant females $(n=20)$ with HG (90\%) compared to $50 \%$ in controls ( $n=10$ ). Although $H$. pylori therapy is generally deferred until postpartum period due to teratogenicity of antibiotics, validation of such association can warrant $H$. pylori therapy for $\mathrm{HG}^{3}$

\section{Maternal Outcomes (-Table 1)}

Data from several studies suggest that EGD is safe in pregnancy and no serious adverse events were reported..$^{1,3,7,8}$ The risk of EGD in pregnancy is similar to that of general population. Pregnant women are generally young to early middle age and likely to have lower complication rates compared to elderly. Hemodynamic instability should be corrected prior to EGD.

\section{Fetal Outcomes}

Most of the reported fetal adverse outcomes (preterm delivery, still births, spontaneous abortion) occurred in high-risk pregnancies and not temporally related to EGD (-Table 1)..$^{1,3,7,8}$ Apgar scores in infants after birth were similar in patients who underwent EGD versus controls. ${ }^{1}$ On fetal cardiac monitoring, fetal heart rate remained normal during EGD. ${ }^{1}$

\section{Therapeutic EGD}

\section{Variceal Bleed}

Extrahepatic portal vein obstruction and noncirrhotic portal fibrosis are the important causes of variceal bleed in pregnancy as fertility is compromised in cirrhosis due to altered estrogen metabolism. The risk of bleeding increases in pregnancy due to increased blood volume and increased peripheral vascular resistance due to compression of inferior vena cava by gravid uterus. The risk of bleeding is highest in second trimester as portal hypertension peaks and during labor due to increased vascular resistance due to performance of Valsalva man oeuvre. De novo variceal hemorrhage and bleeding from preexisting varices occur in 30 and 75\% cases, respectively, in pregnancy. Beta-blockers are useful in reducing portal pressure and should be continued. There is risk of decompensation of preexisting liver disease during variceal bleed in pregnancy leading to poor fetomaternal outcomes 
Table 1 Summary of studies on esophagogastroduodenoscopy (EGD; both diagnostic and therapeutic) and flexible sigmoidoscopy/colonoscopy in pregnancy

\begin{tabular}{|c|c|c|c|c|}
\hline Author & Type of study & $N$ & Maternal outcome & Fetal outcome \\
\hline \multicolumn{5}{|c|}{ Diagnostic EGD } \\
\hline $\begin{array}{l}\text { Cappell et al } \\
(1996)^{7}\end{array}$ & $\begin{array}{l}\text { Retrospective } \\
\text { case-control }\end{array}$ & 83 & $\begin{array}{l}\text { One case of transient pyrexia resolv- } \\
\text { ing spontaneously, adverse pregnancy } \\
\text { outcomes related to high-risk pregnancy } \\
\text { rather than EGD }\end{array}$ & $\begin{array}{l}\text { Health infants in } 95 \% \text { compared to } 94 \% \text { in con- } \\
\text { trols; EGD did not induce abnormal fetal heart } \\
\text { rate during EGD }\end{array}$ \\
\hline $\begin{array}{l}\text { Debby et al } \\
(2008)^{8}\end{array}$ & $\begin{array}{l}\text { Retrospective } \\
\text { clinical series }\end{array}$ & 60 & $\begin{array}{l}\text { No maternal mortality, other complica- } \\
\text { tions not described }\end{array}$ & $\begin{array}{l}\text { Fetal death and induced abortion in } 2 \text { and } 5 \% \text {, } \\
\text { respectively. Eight had preterm delivery. No fetal } \\
\text { malformations reported }\end{array}$ \\
\hline $\begin{array}{l}\text { Bagis et al } \\
(2002)^{3}\end{array}$ & Prospective & 30 & $\begin{array}{l}\text { All } 30 \text { mothers had hyperemesis grav- } \\
\text { idarum. High prevalence of } \mathrm{H} \text {. pylori infec- } \\
\text { tion }(95 \%) \text { compared to } 50 \% \text { in controls }\end{array}$ & Not available \\
\hline $\begin{array}{l}\text { Cappell } \\
(2003)^{51}\end{array}$ & $\begin{array}{l}\text { Literature review } \\
\text { of case reports }\end{array}$ & 27 & $\begin{array}{l}\text { Singe maternal mortality due to meta- } \\
\text { static malignancy }\end{array}$ & 3 cases of stillbirth, 1 abortion, 1 preterm labor \\
\hline \multicolumn{5}{|c|}{ Therapeutic EGD } \\
\hline \multicolumn{5}{|c|}{ Sclerotherapy for esophageal varices } \\
\hline Author & Type of study & $N$ & Maternal outcome & Fetal outcome \\
\hline $\begin{array}{l}\text { Aggarwal } \\
\text { et al }(2001)^{11}\end{array}$ & Case series & 17 & $\begin{array}{l}\text { All patients had acute variceal bleed. } 10 \\
\text { patients with EHPVO and } 7 \text { patients } \\
\text { with NCPF underwent EST with absolute } \\
\text { alcohol or sodium tetradecyl sulfate } 1.5 \% \text {; } \\
12 \text { patients required repeat EST and } 2 \\
\text { required EVL due to failed EST }\end{array}$ & $\begin{array}{l}8 \text { healthy infants ( } 2 \text { preterm), } 3 \text { stillbirths, } 1 \text { neo- } \\
\text { natal death, and } 5 \text { voluntary abortions }\end{array}$ \\
\hline $\begin{array}{l}\text { Kochhar et } \\
\text { al (1990 and } \\
1999)^{9,10}\end{array}$ & Two cases series & 10 & $\begin{array}{l}\text { For active variceal bleed in } 5 \text { and for } \\
\text { prophylaxis in } 5 \text {. Men number of sessions } \\
\text { required were } 3 \text {. Esophageal stricture } \\
\text { dilated with Savary-Gilliard dilator }\end{array}$ & $\begin{array}{l}\text { All delivered at term as healthy infants by normal } \\
\text { vaginal delivery }\end{array}$ \\
\hline $\begin{array}{l}\text { Cappell } \\
(2003)^{51}\end{array}$ & $\begin{array}{l}\text { Review of case } \\
\text { reports }\end{array}$ & 7 & Successful EST for all & All infants were healthy \\
\hline $\begin{array}{l}\text { Mandal et al } \\
(2012)^{12}\end{array}$ & Retrospective & 2 & $\begin{array}{l}\text { Successful EST, better if diagnosed and } \\
\text { treated prior to pregnancy }\end{array}$ & Better if diagnosed prenatally \\
\hline \multicolumn{5}{|c|}{ Endoscopic variceal ligation for esophageal varices } \\
\hline $\begin{array}{l}\text { Mandal } \\
(2012)^{12}\end{array}$ & Retrospective & 8 & $\begin{array}{l}\text { Successful EVL, better if diagnosed and } \\
\text { treated prior to pregnancy }\end{array}$ & Better if diagnosed prenatally \\
\hline $\begin{array}{l}\text { Keepanasseril } \\
\text { et al }(2020)^{13}\end{array}$ & Retrospective & 9 & $\begin{array}{l}\text { Maternal complications similar in NCPF } \\
\text { and EHPVO. DIC, sepsis and AKI may com- } \\
\text { plicate pregnancy }\end{array}$ & $\begin{array}{l}\text { Perinatal outcomes similar with NCPF and EHPVO. } \\
\text { Preterm birth most common fetal complication }\end{array}$ \\
\hline $\begin{array}{l}\text { Dhiman et al } \\
(2000)^{14}\end{array}$ & Case series & 3 & $\begin{array}{l}2 \text { had uncomplicated delivery, one patient } \\
\text { was better until 20th week of gestation } \\
\text { (no further data), successful variceal eradi- } \\
\text { cation with EVL after faded EST }\end{array}$ & Uneventful delivery \\
\hline \multicolumn{5}{|c|}{ Nonvariceal upper GI bleed (NVUGIB) } \\
\hline $\begin{array}{l}\text { Nguyen et al } \\
(2010)^{4}\end{array}$ & $\begin{array}{l}\text { Retrospective } \\
\text { cohort study }\end{array}$ & 1,210 & $\begin{array}{l}\text { Mortality was lower in pregnant women } \\
\text { compared to nonpregnant, age-matched } \\
\text { controls }(n=6,050)\end{array}$ & $\begin{array}{l}\text { The incidence of perinatal complications and } \\
\text { prematurity was similar between the groups who } \\
\text { underwent endoscopy compared to them who } \\
\text { did not }\end{array}$ \\
\hline \multicolumn{5}{|c|}{ Flexible sigmoidoscopy/colonoscopy } \\
\hline $\begin{array}{l}\text { Ko et al } \\
(2020)^{20}\end{array}$ & $\begin{array}{l}\text { Retrospective } \\
\text { cohort study }\end{array}$ & 48 & $\begin{array}{l}\text { No adverse obstetric events temporally } \\
\text { associated with sigmoidoscopy, manage- } \\
\text { ment changed in } 78 \% \text { following pregnancy }\end{array}$ & $\begin{array}{l}\text { Fetal outcomes like prematurity and low birth } \\
\text { weight was more common in IBD population } \\
\text { compared to non-IBD pregnant women }\end{array}$ \\
\hline $\begin{array}{l}\text { Cappell et al } \\
(1996)^{19}\end{array}$ & $\begin{array}{l}\text { Case-control } \\
\text { study }\end{array}$ & 56 & $\begin{array}{l}\text { No complications ( } 48 \text { sigmoidoscopies, } 8 \\
\text { colonoscopies) }\end{array}$ & $\begin{array}{l}\text { Among sigmoidoscopy group, after excluding } \\
\text { voluntary abortions, rest all have delivered } \\
\text { healthy babies ( } 27 \text { at term). } 1 \text { stillbirth, } 1 \text { death } \\
\text { due to prematurity, and } 1 \text { cleft palate was } \\
\text { reported. Complications were not higher com- } \\
\text { pared to control pregnant female who did not } \\
\text { undergo sigmoidoscopy. Adverse outcomes were } \\
\text { unrelated to colonoscopy }\end{array}$ \\
\hline
\end{tabular}


Table 1 (continued)

\begin{tabular}{|l|l|l|l|l|}
\hline Author & Type of study & $\mathbf{N}$ & Maternal outcome & Fetal outcome \\
\hline $\begin{array}{l}\text { Cappell et al } \\
(2010)^{21}\end{array}$ & $\begin{array}{l}\text { Case-control } \\
\text { study }\end{array}$ & 20 & $\begin{array}{l}\text { 16 colonoscopies in second trimes- } \\
\text { ter, 2 each in first and third trimester. } \\
\text { Colonoscopy led to change in manage- } \\
\text { ment in 35\% cases. 2 cases with mild } \\
\text { transient hypotension }\end{array}$ & $\begin{array}{l}\text { No abnormal fetal heart rate during procedure. } \\
1 \text { involuntary abortion and 1 with congenital } \\
\text { abnormality. Trend of better fetal outcomes } \\
\text { (lower prematurity, abortion, higher birth weight, } \\
\text { similar APGAR score, and congenital anomaly) in } \\
\text { cases compared to controls }\end{array}$ \\
\hline $\begin{array}{l}\text { De Lima et al } \\
(2015)^{23}\end{array}$ & $\begin{array}{l}\text { Systematic } \\
\text { review }\end{array}$ & 164 & $\begin{array}{l}\text { Above two studies plus 92 cases in case } \\
\text { reports. 100 lower Gl endoscopies in case } \\
\text { reports (1 spontaneous abortion in first } \\
\text { trimester, 1 induced abortion in second tri- } \\
\text { mester, induction of labor and emergency } \\
\text { caesarean section in 1 each) }\end{array}$ & $\begin{array}{l}\text { Two fetal deaths, both in second trimester among } \\
100 \text { lower Gl endoscopies in case reports }\end{array}$ \\
\hline $\begin{array}{l}\text { de Lima et al } \\
(2015)^{2}\end{array}$ & $\begin{array}{l}\text { Prospective study } \\
\text { (IBD) }\end{array}$ & 42 & $\begin{array}{l}\text { 2 spontaneous abortions were related to } \\
\text { procedure, but abortion rate not higher } \\
\text { compared to controls } \\
\text { (47 procedures, 12 colonoscopy, 35 } \\
\text { sigmoidoscopy) }\end{array}$ & $\begin{array}{l}\text { Median birth weight was lower compared to } \\
\text { controls, however, prematurity, congenital mal- } \\
\text { formations, and APGAR scores were not different } \\
\text { compared to controls }\end{array}$ \\
\hline
\end{tabular}

Abbreviations: AKI, acute kidney injury; APGAR, Appearance, Pulse, Grimace, Activity, and Respiration; DIC, disseminated intravascular coagulation; EHPVO, extrahepatic portal vein obstruction; EST, endoscopic sclerotherapy; EVL, endoscopic variceal ligation; GI, gastrointestinal; IBD, inflammatory bowel disease; NCPF, noncirrhotic portal fibrosis.

and hence prophylactic treatment should be considered whenever pregnancy is contemplated.

Fetal outcomes are favorable (100\%) in a study by Kochhar et al compared to that by Aggarwal et al (67\%) with regard to endoscopic sclerotherapy (EST) which is mainly due to lower incidence of acute variceal bleed in the former (50 vs. $100 \%$ in the later) (-Table 1). ${ }^{9-11}$ The data regarding safety of endoscopic variceal ligation (EVL) is also limited to case series (- Table 1). ${ }^{12-14} \mathrm{EVL}$ is preferred over EST in pregnancy due to lower incidence of complications, higher efficacy, and conflicting reports on fetal outcomes with EST.

\section{Nonvariceal Upper GI Bleed}

The most common cause of nonvariceal upper GI bleed (NVUGIB) in pregnant women is Mallory-Weiss tear (25\%) followed by gastritis (12\%), PUD (6.8\%), esophagitis (2.5\%), anastomotic ulcer $(0.2 \%)$, and Dieulafoy's lesion/arteriovenous malformation $(0.1 \%)$ according to a nationwide study $(n=1,210) .{ }^{4} \mathrm{~A}$ conservative, nonendoscopic management of NVUGIB in pregnant women is not associated with increased fetomaternal complications according to the study. Fetal outcomes were not different compared to controls. Hence, therapeutic EGD is safe in actively bleeding pregnant patients. ${ }^{4}$ Rest of the studies are limited to case reports.

The data regarding NVUGIB in pregnancy is difficult to extrapolate given the variety of procedures performed for NVUGIB (epinephrine/glue/thrombin/saline injection, electro/photo/thermo/argon plasma coagulation, or mechanical therapy with hemoclips) and various causes with different stigmata of bleed (active spurt/ooze, nonbleeding visible vessel, and adherent clot). ${ }^{1}$

Special considerations should be made during electrocoagulation and epinephrine injection. During electrocoagulation, the grounding pad should be kept in such a way from the interventional catheter that the current does not traverse the uterus/fetus. Epinephrine (pregnancy category C) exposure during first trimester has been associated with congenital malformation, although it could be due to high-risk pregnancy. ${ }^{1}$

\section{Endoscopic Therapy for Achalasia}

Achalasia during pregnancy can be confused with reflux and hyperemesis. The goal of treatment during pregnancy is to avoid maternal malnutrition and consequent fetal growth retardation and death. Nutrition can be managed initially with nasogastric feeding or parenteral nutrition. In case of intolerance or refusal, botulinum toxin (BT) injection at lower esophageal sphincter or pneumatic balloon dilation (PBD) can be performed..$^{15}$ There are five case reports of BT injection for achalasia during pregnancy mainly in the second and third trimester. There are seven case reports of PBD in achalasia with pregnancy. ${ }^{15}$ These modalities can have transient effect with recurrence but can be helpful to tide over the crisis. Currently, there are no case reports of peroral endoscopic myotomy (POEM) for achalasia in pregnancy although it could be an effective treatment. There is only one case report of laparoscopic Heller's myotomy (LHM) in second trimester. POEM or LHM can only be considered in resistant cases where PBD and BT fails. ${ }^{15}$

\section{Endoscopy to Improve Maternal Nutrition}

\section{Percutaneous Endoscopic Gastrostomy and Percutaneous Endoscopic Gastrojejunostomy}

Enteral nutrition with percutaneous endoscopic gastrostomy (PEG) or percutaneous endoscopic gastrojejunostomy (PEG- J) may be indicated in pregnancy if maternal nutrition is compromised due to dysphagia, severe odynophagia, obstruction at gastroesophageal junction, intractable HG, 
eating disorders like anorexia nervosa, chronic intestinal pseudo-obstruction, and neurologic disorders precluding deglutition like motor neurone disease, myotonic dystrophy, or massive stroke. PEG can be beneficial in maintaining maternal nutrition thus improving fetal outcomes as seen in five out of six case reports. Fetal adverse outcome is mainly related to maternal high-risk condition rather than PEG. ${ }^{1}$

Precautions like ultrasound-guided marking of upper border of uterus should be done prior to PEG to avoid inadvertent uterine puncture. Gravid uterus can cause gastric compression leading to pain and leak around stoma. Feeding tube can be placed via the gastrostomy into the jejunum (PEG-J) in case of refractory nausea, vomiting, and aspiration (five cases reports). ${ }^{1}$

\section{Flexible Sigmoidoscopy and Colonoscopy}

\section{Preparations}

Sigmoidoscopy preparation with tap water, saline, or sodium phosphate enema can lead to fluid shifts and volume overload/dehydration along with dyselectrolytemia. Chronic use may cause dyselectrolytemia and fetal bone demineralization/growth failure. However, risks are negligible in pregnant female without heart failure, chronic renal insufficiency, or dehydration. ${ }^{1}$

Among orally administered preparations, polyethylene glycol (isotonic, pregnancy category C) is preferred over sodium phosphate preparations as the later can lead to dyselectrolytemia and even renal insufficiency in at-risk or dehydrated patients with consequent effects on fetus. ${ }^{16}$ In a prospective study of pregnant patients with constipation, polyethylene glycol relieved constipation in three-fourths without any complications. ${ }^{17}$

\section{Indications}

Acute lower GI bleeding (except in suspected hemorrhoids), sigmoid/rectal mass, or stricture are strong indications of flexible sigmoidoscopy in pregnancy. Severe, persistent diarrhea and severe flare of inflammatory bowel disease are moderate indications and investigation of lower abdominal pain/altered bowel habits are weak indications. Volvulus is an indication of emergency surgery as it can lead to worse fetomaternal outcomes. Reports have described successful decompression of sigmoid volvulus by sigmoidoscopy. ${ }^{18}$ The diagnostic value of sigmoidoscopy is highest for hematochezia (76\%) compared to other indications (29\%). ${ }^{19}$ Reported change in management after sigmoidoscopy/colonoscopy ranges from 35 to $78 \% .^{19-21}$

Therapeutic sigmoidoscopy to release uterine incarceration have been reported in five patients by Seubert et al..$^{22}$

\section{Maternal and Fetal Outcomes}

The maternal and fetal outcomes from retrospective and prospective studies and systematic review including various case reports indicate highly favorable fetomaternal outcomes (-Table 1). ${ }^{19-23}$ Maternal complications were transient, self-limited, or unrelated to procedure. Poor fetal outcomes correlated with high-risk pregnancy. Congenital anomalies were not higher compared to controls. These data suggest safety of sigmoidoscopy when performed for strong indications.

The data for colonoscopy in pregnancy is, however, relatively scanty with strongest evidence in second trimester with lowest risk for fetus. Colonoscopy in first trimester can induce premature labor/neonatal depression. Colonoscopy should generally be deferred in all the trimesters of pregnancy for elective indications. Despite the fact that colonoscopy can be technically difficult due to distortion of normal landmarks in pregnancy, cecal intubation rates are high.

\section{Endoscopic Retrograde Cholangiopancreatography}

\section{Risks of ERCP}

Pregnancy increases gallstone formation as estrogen promotes cholesterol synthesis leading to supersaturation of bile and progesterone inhibits gallbladder contractility. Choledocholithiasis complicated by jaundice, pancreatitis, or cholangitis can be treated safely by therapeutic ERCP in pregnant women as compared to complex biliary surgery which increases risk of fetal loss. As compared to EGD, unique risk of ERCP in pregnancy includes radiation exposure. The teratogenic dose of radiation in first trimester is above $50 \mathrm{mGy}{ }^{24}$ Small studies have shown that fetal radiation exposure up to $3.1 \mathrm{mGy}$ can occur during ERCP which is significantly lower than the acceptable threshold. ${ }^{25}$ However, more recent studies have shown that fetal radiation dose may not be trivial and exceed $10 \mathrm{mGy}$ when total dose area product was calculated. ${ }^{26}$ Prolonged procedure and duodenal intubation time, requirement of higher anesthetic doses, and risk of postsphincterotomy bleeding/perforation are the other unique risks with ERCP.

\section{Clinical Evidence}

Until recently, the data regarding safety of ERCP in pregnancy was based on several retrospective small series of total 350 patients. ${ }^{27} \mathrm{~A}$ nationwide cohort study published in 2015 consisting of 907 pregnant women undergoing ERCP represents the highest study population until now. This matched control study by Inamdar et al have shown that complications of ERCP were similar in pregnant as compared to nonpregnant women although risk of post-ERCP pancreatitis (PEP) was considerably higher in pregnant (adjusted odds ratio [aOR]: 2.8), more so in nonteaching hospitals (aOR: 3.5). ${ }^{28}$ Fetomaternal outcomes were noninferior to national rates. ${ }^{28}$ Pregnancy was an independent risk factor for PEP. This data emphasizes the fact that although ERCP is safe in pregnancy, it should be done in carefully selected cases with due precautions in specialized centers.

There are several retrospective studies, case series, and reports of ERCP in pregnancy. We have summarized the results of these studies with sample size $(n \geq 10)$ in - Table 2. ${ }^{25,28-41}$ The limitations of existing studies are retrospective in nature (only one prospective), missing fetal 
144 Endoscopy in Pregnancy Pal et al.

Table 2 Summary of studies (sample size: $\mathrm{n} \geq 10$ ) on endoscopic retrograde cholangiopancreatography (ERCP) in pregnancy

\begin{tabular}{|c|c|c|c|c|c|c|c|c|}
\hline Author & Year & Number & Study type & $\begin{array}{l}\text { Gestation } \\
\text { (trimester) }\end{array}$ & Intervention & $\begin{array}{l}\text { Imaging } \\
\text { modality }\end{array}$ & Complication & Fetal outcomes \\
\hline $\begin{array}{l}\text { Jamidar } \\
\text { et al } 29\end{array}$ & 1995 & 29 & Retrospective & $\begin{array}{l}1 \text { st } 15 \\
\text { 2nd } 8 \\
3 \text { rd } 6\end{array}$ & $\begin{array}{l}\text { BES-14 Biliary stent-1 } \\
\text { Minor papilla ES-1 } \\
\text { PD stent-1 }\end{array}$ & $\begin{array}{l}\text { Fluoroscopy } \\
\text { time not } \\
\text { reported }\end{array}$ & $\begin{array}{l}\text { Post-ERCP } \\
\text { Pancreatitis : PEP-1 }\end{array}$ & $\begin{array}{l}\text { Spontaneous } \\
\text { abortion-1 } \\
\text { Neonatal death -1 } \\
\text { Preterm-1 }\end{array}$ \\
\hline $\begin{array}{l}\text { Farca } \\
\text { et } a^{30}\end{array}$ & 1997 & 10 & Prospective & Not known & BES+ stent -10 & Fluoroscopy & $\begin{array}{l}\text { Impacted stone } \\
\text { requiring repeat } \\
\text { ERCP-1 }\end{array}$ & None \\
\hline $\begin{array}{l}\text { Tham } \\
\text { et al } 25\end{array}$ & 2003 & 15 & Retrospective & $\begin{array}{l}\text { 1st } 1 \\
\text { 2nd } 5 \\
\text { 3rd } 9\end{array}$ & \begin{tabular}{|l} 
ES-6 \\
Biliary stent-1
\end{tabular} & $\begin{array}{l}\text { Median fluoros- } \\
\text { copy time } 3.2 \\
\text { min }\end{array}$ & Mild PEP - 1 & None \\
\hline $\begin{array}{l}\text { Kahaleh } \\
\text { et al }\end{array}$ & 2004 & 17 & Retrospective & $\begin{array}{l}\text { No } \\
\text { information }\end{array}$ & BES-17 & $\begin{array}{l}\text { Median fluoros- } \\
\text { copy time - } 14 \mathrm{~s}\end{array}$ & $\begin{array}{l}\text { Post ES bleed-1 } \\
\text { PEP-1 } \\
\text { Pre-ecalampsia-1 }\end{array}$ & None \\
\hline $\begin{array}{l}\text { Gupta } \\
\text { et } \mathrm{al}^{32}\end{array}$ & 2005 & 18 & Retrospective & $\begin{array}{l}\text { 1st } 4 \\
\text { 2nd } 6 \\
\text { 3rd } 8\end{array}$ & $\begin{array}{l}\text { CBD clearance - } 14 \\
\text { Stents-4 }\end{array}$ & \begin{tabular}{|l|} 
Fluoroscopy -11 \\
USG-5 \\
Bile aspiration-2
\end{tabular} & $\begin{array}{l}\text { Mild PEP-1 } \\
\text { Post-ES Bleed-1 }\end{array}$ & Preterm-1 \\
\hline $\begin{array}{l}\text { Sharma } \\
\text { and } \\
\text { Maharshi }^{33}\end{array}$ & 2008 & 11 & Retrospective & $\begin{array}{l}\text { No } \\
\text { information }\end{array}$ & $\begin{array}{l}\text { ES }=11 \\
\text { Stent }=11 \\
\text { Mechanical litho- } \\
\text { tripsy }=1\end{array}$ & Not used & $\begin{array}{l}\text { None, } 1 \text { required } \\
\text { surgery postpartum } \\
\text { for large stones }\end{array}$ & No adverse outcomes \\
\hline $\begin{array}{l}\text { Shelton } \\
\text { et al }{ }^{34}\end{array}$ & 2008 & 21 & Retrospective & $\begin{array}{l}\text { 1st } 7 \\
\text { 2nd } 9 \\
\text { 3rd } 5\end{array}$ & $\begin{array}{l}\text { ES- } 21 \\
\text { EUS-6 } \\
\text { Choledochoscopy-5 }\end{array}$ & \begin{tabular}{|l|} 
Not used \\
EUS/MRCP \\
Wire-guided bile \\
observation
\end{tabular} & Mild PEP-1 (4.8\%) & 1-IUGR \\
\hline Tang et al ${ }^{35}$ & 2009 & 65 & Retrospective & $\begin{array}{l}\text { 1st } 17 \\
\text { 2nd 20 } \\
\text { 3rd 31 }\end{array}$ & $\begin{array}{l}\text { ES-64 } \\
\text { Biliary stent-16 } \\
\text { Mechanical } \\
\text { lithotripsy-1.5\% } \\
\text { Precut and } \\
\text { Prophylactic PD } \\
\text { stent-2.9\% }\end{array}$ & $\begin{array}{l}\text { Median fluoros- } \\
\text { copy time: } 1.45 \\
\text { min }\end{array}$ & $\begin{array}{l}\text { Mild PEP-16\% } \\
\text { Minor bleeding 7.4\% }\end{array}$ & $\begin{array}{l}\text { First trimester ERCP: } \\
\text { Preterm-20\% } \\
\text { LBW-21.4\% }\end{array}$ \\
\hline $\begin{array}{l}\text { Bani Hani } \\
\text { et } a^{36}\end{array}$ & 2009 & 10 & Retrospective & $\begin{array}{l}\text { 1st } 2 \\
\text { 2nd } 5 \\
3 \text { rd 3 }\end{array}$ & ES-10 & $\begin{array}{l}\text { Fluoroscopy } \\
\text { all- duration } \\
\text { Unknown }\end{array}$ & PEP-1 (10\%) & None \\
\hline Daas et al ${ }^{137}$ & 2009 & 17 & Retrospective & $\begin{array}{l}1 \text { st } 2 \\
\text { 2nd 3 } \\
\text { 3rd } 17\end{array}$ & $\begin{array}{l}\text { ES-10 } \\
\text { Biliary stent-4 }\end{array}$ & $\begin{array}{l}\text { Mean fluoros- } \\
\text { copy time } 8 \mathrm{~s}\end{array}$ & Nil & None \\
\hline $\begin{array}{l}\text { García- } \\
\text { Cano } \\
\text { et al }{ }^{38}\end{array}$ & 2012 & 11 & Retrospective & $\begin{array}{l}\text { 1st } 1 \\
\text { 2nd } 4 \\
3 \text { rd } 6\end{array}$ & $\begin{array}{l}\text { ES-9 } \\
\text { Stent -2 }\end{array}$ & $\begin{array}{l}\text { Fluoroscopy } 5 \\
\text { cases (median } \\
\text { time } 30 \text { s) }\end{array}$ & Hyperamylasemia-1 & None \\
\hline $\begin{array}{l}\text { Zhou } \\
\text { et al }{ }^{39}\end{array}$ & 2013 & 17 & Retrospective & All 3rd & $\begin{array}{l}\text { NBD-7 } \\
\text { Biliary stent-10 }\end{array}$ & $\begin{array}{l}\text { Fluoroscopy } \\
\text { time not } \\
\text { reported }\end{array}$ & $\begin{array}{l}\text { Post ES bleed-1 } \\
\text { PEP-1 }\end{array}$ & 6 preterm \\
\hline $\begin{array}{l}\text { Ersoz } \\
\text { et al }\end{array}$ & 2016 & 22 & Retrospective & $\begin{array}{l}1 \text { st } 2 \\
\text { 2nd 3 } \\
3 \text { rd } 17\end{array}$ & $\begin{array}{l}E S=22 \\
E P B D-22\end{array}$ & Not used & Mild PEP-2/22 & None \\
\hline $\begin{array}{l}\text { Inamdar } \\
\text { et } \mathrm{al}^{28}\end{array}$ & 2016 & 907 & $\begin{array}{l}\text { National data } \\
\text { base review }\end{array}$ & $\begin{array}{l}\text { No } \\
\text { information }\end{array}$ & No information & No information & $\begin{array}{l}\text { PEP-12.13\% } \\
\text { vs. 5\% in matched } \\
\text { controls }\end{array}$ & $\begin{array}{l}\text { Preterm-1.87\% } \\
\text { Fetal distress-0.33\% } \\
\text { Fetal loss- } 0.67 \%\end{array}$ \\
\hline \begin{tabular}{l|} 
Konduk \\
and \\
Bayraktar ${ }^{41}$
\end{tabular} & 2019 & 25 & Retrospective & $\begin{array}{l}1 \text { st } 2 \\
\text { 2nd 3 } \\
3 \text { rd } 17\end{array}$ & $\begin{array}{l}\text { ES-25 } \\
\text { Stone extraction-18 }\end{array}$ & $\begin{array}{l}\text { Fluoroscopy-18 } \\
\text { (6 s) } \\
\text { Nonradiation-7 }\end{array}$ & None & None \\
\hline
\end{tabular}

Abbreviations: BES, biliary endoscopic sphincterotomy; CBD, common bile duct; EPBD, endoscopic papillary balloon dilation; ES, endoscopic sphincterotomy; EUS, endoscopic ultrasound; IUGR, intrauterine growth retardation; NBD, nasobiliary drain; PEP, post-ERCP pancreatitis; USG, ultrasound. 
outcomes (10-40\%), limited follow-up after birth, and lack of control. ${ }^{1}$ A large study with control group is required to investigate whether ERCP increases the background risk of teratogenicity (1.8\%).

\section{ERCP Interventions in Pregnancy}

Interventions described during ERCP in pregnancy include endoscopic biliary sphincterotomy with or without biliary stenting, biliary stenting alone, balloon sweep without sphincterotomy, endoscopic papillary balloon dilation, mechanical lithotripsy, precut sphincterotomy, pancreatic stent placement, nasobiliary tube placement, and choledochoscopy ( - Table1).

\section{Repeat or Failed ERCP}

Technical success is generally high (>90\%). A repeat ERCP/surgery is required due to recurrent biliary disease in $<10 \%$ patients (24/296). Failed ERCP was reported in < 5\% (14/296) patients. ${ }^{1}$

\section{Maternal Considerations}

The risk of post-ERCP complications (bleeding, perforation) are similar in pregnancy compared to nonpregnant (bleeding risk 2\%) except for higher risk of PEP. ${ }^{28}$ This is contrary to earlier data describing similar risk of PEP in pregnancy compared to nonpregnant. However, the risk is small and clinically acceptable. Lack of liberal use of intravenous hydration, teratogenic rectal nonsteroidal anti-inflammatory drugs, or an inherent physiological mechanism could explain this. ${ }^{28}$ PEP in pregnancy is mostly mild-moderately severe.

Rates of postsphincterotomy bleeding in pregnancy (1\%) are lower than general population (2\%) and similar to age-matched nonpregnant females $(0.96 \%){ }^{28}$ Most of the bleeding can be tackled endoscopically. Pregnancy being a mild hypercoagulable state, does not lead to increased bleeding tendency.

Rate of perforation was comparable in pregnant versus nonpregnant age-matched female during ERCP. ${ }^{28}$ Postsphincterotomy bilioenteric fistula were reported to be successfully treated with biliary stenting. ${ }^{42}$

Maternal outcomes in those undergoing ERCP is similar to other pregnant women with no increase in maternal mortality. ${ }^{28}$

\section{Fetal Considerations}

Based on an earlier review of literature, among 296 pregnancies fatal outcomes were not reported in 42 cases. Majority had normal term delivery $(n=237)$ and rest had premature birth $(n=11)$, spontaneous abortion $(n=3)$, sudden death after birth $(n=2)$, and induced abortion $(n=1)$. Overall, perinatal mortality was less than $1 \%$ with no congenital anomalies. ${ }^{1}$ However, most of the studies did not look specifically for congenital anomalies and follow-up after birth was limited. Data from national database study showed that the rate of prematurity (1.87\%) was lower compared to national average (11.5\%). Fetal distress/loss was seen in $1 \%$ cases similar to population rates. ${ }^{28}$ The data is reassuring and suggests that the fetal risk is small and acceptable although comparatively higher than maternal risk. Overall benefits of ERCP in complicated choledocholithiasis seem to outweigh the risks.

\section{Technical Modifications and Considerations for Radiation-Free ERCP or Reduction in Radiation Exposure during Therapeutic ERCP in Pregnancy}

Various technical modifications and procedural strategies like (1) wire-guided bile observation, (2) stent-guided/precut sphincterotomy for biliary access, (3) EUS guidance, (4) spy cholangioscopy, (5) expert endoscopist (reduce radiation exposure by shorter procedure time), (6) two-staged ERCP, (7) contrast-enhanced ultrasound-guided ERCP, and (8) technical modifications in X-ray technique have been described to minimize fetal radiation exposure during ERCP which are listed in - Table 3. ${ }^{29,33,34,43-55}$

Earlier reports focused on wire-guided bile aspiration, precut sphincterotomy, and lead shielding to reduce radiation exposure. ${ }^{53,55}$ Later on, modification in fluoroscopy techniques have been described. ${ }^{51,52}$ Two-staged procedures with nasobiliary drain and stent placement has also been described. ${ }^{33,39,40}$ The recent trend is toward radiation-free, single-session ERCP in pregnancy with either EUS guidance or by digital single-operator cholangioscopy (DSOC). ${ }^{43,46-48}$

\section{Endoscopic Spyscopy}

Spyscope/baby scope introduced through the biopsy channel of ERCP scope can be used to confirm common bile duct (CBD) stone clearance postsphincterotomy and evaluate intracholedochal tumor or stricture. Five such cases have been described in the literature without any adverse maternal outcomes. ${ }^{34}$ Spyscopy has been described along with EUS guidance for management of CBD stone in pregnancy. ${ }^{56}$

Cholangioscopy has been revolutionized with the use of DSOC (SpyGlass DS, Boston Scientific) with disposable cholangioscope and digital image capture. This results in better image quality and maneuverability with advantages like feasibility of radiation-free ERCP, direct visualization of the biliary system, ability for tissue acquisition, and cholangioscopy-directed therapy. ERCP guided by DSOC can help avoid radiation in 50\% cases as shown in a recent study. ${ }^{43}$ Fetal outcomes have not been described in these reports. Larger studies reporting fetomaternal outcomes are required to establish this attractive radiation-free 
Table 3 Summary of studies describing technical modifications to reduce radiation exposure during therapeutic endoscopic retrograde cholangiopancreatography (ERCP) in pregnancy

\begin{tabular}{|c|c|c|}
\hline Author & Modified ERCP techniques & Rationale \\
\hline $\begin{array}{l}\text { Brewer et al } \\
(2021)^{43}\end{array}$ & $\begin{array}{l}\text { Digital single operator cholangioscopy (DSOC)-guided } \\
\operatorname{ERCP}(n=10)\end{array}$ & $\begin{array}{l}\text { Fluoroscopy-less ERCP in } 50 \% \text { cases, safe and feasible alternative } \\
\text { to standard ERCP, acceptable maternal and fetal safety profile }\end{array}$ \\
\hline $\begin{array}{l}\text { Sharma and } \\
\text { Maharshi } \\
(2008)^{33}\end{array}$ & $\begin{array}{l}\text { Two-stage technique: ES + stenting without fluoroscopy in } \\
\text { pregnancy followed by definitive ERCP postpartum }\end{array}$ & Avoidance of radiation exposure \\
\hline $\begin{array}{l}\text { Ersoz et al } \\
(2016)^{40}\end{array}$ & $\begin{array}{l}\text { ES followed by endoscopic papillary balloon dilation (EPBD) } \\
\text { and balloon sweep }\end{array}$ & Nonradiation technique to facilitate complete stone removal \\
\hline $\begin{array}{l}\text { Shelton et al } \\
(2008)^{34}\end{array}$ & $\begin{array}{l}\text { Catheter bile aspiration followed by wire-guided bile obser- } \\
\text { vation or stent-guided biliary sphincterotomy or precut } \\
\text { sphincterotomy and finally spy cholangioscopy }\end{array}$ & $\begin{array}{l}\text { Nontraditional techniques for ERCP with increase in efficacy } \\
\text { with wire-guided observation and spy cholangioscopy }\end{array}$ \\
\hline $\begin{array}{l}\text { Zhou et al } \\
(2013)^{39}\end{array}$ & $\begin{array}{l}\text { Nasobiliary drain or stent followed by definite ERCP } \\
\text { postpartum for third trimester pregnancy presenting with } \\
\text { cholangitis }\end{array}$ & $\begin{array}{l}\text { Modified ERCP protocol in 3rd trimester acute cholangitis by } \\
\text { initial temporizing measure and later definitive therapy }\end{array}$ \\
\hline $\begin{array}{l}\text { Polydorou } \\
\text { et al } \\
(2012)^{44}\end{array}$ & $\begin{array}{l}\text { Magnetic resonance cholangiopancreatography (MRCP) } \\
\text { and nonradiation ERCP followed by immediate laparo- } \\
\text { scopic cholecystectomy in biliary pancreatitis }\end{array}$ & $\begin{array}{l}\text { MRCP to clarify the number of stones to guide nonradiation } \\
\text { ERCP }\end{array}$ \\
\hline $\begin{array}{l}\text { Huang et al } \\
(2013)^{45}\end{array}$ & $\begin{array}{l}\text { Comparison of ultrasound guidance for ERCP versus nonra- } \\
\text { diographic ERCP }\end{array}$ & $\begin{array}{l}\text { Higher success rate of complete stone removal, shorter } \\
\text { hospital stay, and lower complication rates with ultrasound } \\
\text { guidance for ERCP; confirm biliary cannulation by ultrasound }\end{array}$ \\
\hline $\begin{array}{l}\text { Sethi et al } \\
(2015)^{46}\end{array}$ & $\begin{array}{l}\text { EUS guidance followed by same session ERCP with or with- } \\
\text { out spy cholangioscopy }\end{array}$ & Safe and effective radiation-free ERCP in pregnant patients \\
\hline $\begin{array}{l}\text { Götzberger } \\
\text { et al } \\
(2012)^{47}\end{array}$ & $\begin{array}{l}\text { EUS followed by contrast-enhanced ultrasound-guided } \\
\text { ERCP by injecting ultrasound contest agent via ERCP } \\
\text { catheter }\end{array}$ & $\begin{array}{l}\text { Intraductal application of ultrasound contrast clearly deline- } \\
\text { ates biliary pathology }\end{array}$ \\
\hline $\begin{array}{l}\text { Vohra et al } \\
(2014)^{48}\end{array}$ & $\begin{array}{l}\text { Single session EUS followed by scheduled ERCP: If endo- } \\
\text { scopic ultrasound (EUS) confirms no stone, ERCP can be } \\
\text { avoided; if EUS shows stones, it helps to give idea about } \\
\text { location, size and number of stones, guide therapy, and } \\
\text { confirm stone clearance }\end{array}$ & $\begin{array}{l}\text { Confirm CBD stone and guide therapy and guide nonradia- } \\
\text { tion intervention }\end{array}$ \\
\hline $\begin{array}{l}\text { Bar-Meir } \\
\text { and } \\
\text { Rotmensch } \\
(1984)^{49}\end{array}$ & $\begin{array}{l}\text { Use of ultrathin caliber baby cholangioscope through } \\
\text { biopsy channel of side view endoscope }\end{array}$ & $\begin{array}{l}\text { Investigation of obstructive jaundice without radiation } \\
\text { exposure }\end{array}$ \\
\hline $\begin{array}{l}\text { Baillie et al } \\
(1990)^{50}\end{array}$ & $\begin{array}{l}\text { Place lead shielding over mother's abdomen and radia- } \\
\text { tion dosimetry badge to monitor radiation. Reduction } \\
\text { in fluoroscopy time and avoiding spot radiographs for } \\
\text { documentation }\end{array}$ & Methods to reduce radiation exposure during ERCP \\
\hline $\begin{array}{l}\text { Cappell } \\
(2003)^{51}\end{array}$ & $\begin{array}{l}\text { Modern X-ray machine, consulting tradition physicist, } \\
\text { attending anesthesiologist, avoiding fellow participa- } \\
\text { tion, deferring to second trimester if possible, minimize } \\
\text { procedure time, referral to tertiary center, prior obstetric } \\
\text { consultation, and informed consent }\end{array}$ & $\begin{array}{l}\text { Reduction in radiation scatter and overall reduction in radia- } \\
\text { tion exposure }\end{array}$ \\
\hline $\begin{array}{l}\text { Baron and } \\
\text { Schueler } \\
(2009)^{52}\end{array}$ & $\begin{array}{l}\text { Avoid magnification fluoroscopy image, adjust maternal } \\
\text { position in fluoroscopy table, digital image acquisition } \\
\text { instead of film-screen radiography, variable rate pulsed } \\
\text { fluoroscopy rather than continuous fluoroscopy, beam } \\
\text { collimation to smallest field, placing image receptor close } \\
\text { to patient, and X-ray tube as far as possible }\end{array}$ & Technical modifications to reduce fetal radiation exposure \\
\hline $\begin{array}{l}\text { Jamidar } \\
\text { et al } \\
(1995)^{29}\end{array}$ & $\begin{array}{l}\text { Performing pregnancy test prior to ERCP in right clinical } \\
\text { setting (missed period in menstruating female), direct } \\
\text { sphincterotome cannulation }\end{array}$ & $\begin{array}{l}\text { Avoid ERCP in unrecognized pregnancy, reduce procedure } \\
\text { time }\end{array}$ \\
\hline $\begin{array}{l}\text { Binmoeller } \\
\text { and Katon } \\
(1990)^{53}\end{array}$ & Needle knife precut sphincterotomy & Reduction in fluoroscopy time \\
\hline $\begin{array}{l}\text { Nesbitt et al } \\
(1996)^{54}\end{array}$ & Magnesium administration for tocolysis & Decrease biliary tract spasm \\
\hline $\begin{array}{l}\text { Rahmin et al } \\
(1994)^{55}\end{array}$ & Bile aspiration to confirm CBD cannulation & Avoid radiation exposure \\
\hline
\end{tabular}

Abbreviations: CBD, common bile duct; ES, endoscopic sphincterotomy; EUS, endoscopic ultrasound. 
technology as an alternative to therapeutic ERCP for CBD stones in pregnancy.

\section{Endoscopic Ultrasound}

EUS is safe in pregnancy as it involves EGD followed by ultrasound examination of pancreaticobiliary tract. ${ }^{57}$ However, EUS may require prolonged procedure time exposing the mother to higher anesthetic doses and the indicated patients could be sicker (e.g., biliary pancreatitis) compared to those undergoing EGD. Clinical data in EUS safety in pregnancy is limited to small case series. In the largest series, Shelton et al used EUS in suspected CBD stone. ${ }^{34}$ Adverse fetal outcomes like death due to recurrent cholangitis and HELLP syndrome are mostly unrelated to EUS and due to severe maternal illness and conservative management of biliary pancreatitis. ${ }^{58}$ Hence, in the absence of strong clinical data, EUS should be used if there is intermediate probability of CBD stone and magnetic resonance cholangiopancreatography is not desirable. EUS can be done in the same session prior to ERCP. ${ }^{48,59}$ Performing ERCP through linear echo-endoscope ultrasound guidance has been described. ${ }^{60}$

\section{Small Bowel Endoscopy}

\section{Enteroscopy}

Enteroscopy in pregnancy is technically difficult due to compression of small bowel loops by gravid uterus precluding deep intubation. The challenges of performing enteroscopy in pregnancy are prolonged procedure time, higher requirement of anesthetic doses, and possibility of placental abruption due to pressure from enteroscope. There is currently no published clinical data on enteroscopy in pregnant females. Only indication of balloon-assisted enteroscopy could be small bowel tumor presumed to be malignant and life-threatening small bowel bleeding not reachable by push enteroscopy. Push enteroscopy could be technically easier given no need for deep small bowel intubation and shorter procedure time than balloon-assisted enteroscopy. Spiral enteroscopy is contraindicated in pregnancy. ${ }^{1}$

\section{Video Capsule Endoscopy}

Video capsule endoscopy (VCE) is an attractive option in pregnancy for small bowel imaging due to absence of radiologic exposure and need for deep enteroscopy although there is concern regarding microwave emission from active capsule. Prolonged small bowel transit in pregnancy due to inhibitory effect of progestin on small bowel smooth muscle contractility can theoretically increase the risk of capsule retention in pregnancy and can lead to incomplete small bowel examination. However, two cases of VCE have been described in the literature. In a case of esophageal varices postsclerotherapy, esophageal VCE ruled out active bleeding from esophageal varices resulting in normal delivery. ${ }^{61}$ In the another case with active small bowel bleed, jejunal ulcerated lesion was identified which turned out to be carcinoid. ${ }^{62}$ In one case of Crohn's disease with missed retained capsule became pregnant which led to ileal resection. ${ }^{63}$ Hence, VCE can be beneficial in pregnancy if strongly indicated unless other risk factors of retention are present.

\section{Endoscopic Cystogastrostomy}

Twocases of endoscopic cystogastrostomy havebeendescribed in the literature under abdominal ultrasound guidance (not EUS) at 17th and 21 st week of gestation. ${ }^{64,65}$ Postprocedure pain and leucocytes have been described which was successfully treated with antibiotics and placement of additional cyst-gastric stents. Hence, endoscopic cystogastrostomy in the current era with EUS guidance is a useful option in pregnant female with symptomatic pancreatic fluid collections as an alternative to surgical cystogastrostomy. Proper informed consent and explanation of alternative modalities of treatment are essential in these settings.

\section{Conclusion}

This review highlights the fact that endoscopy should be done in pregnancy only if strongly indicated. Whenever possible it is wise to defer endoscopy in first trimester and peripartum period unless an emergency like significant GI bleed or suspected malignancy is present. Minimally invasive, short-duration procedures should be substituted for long invasive procedures (e.g., flexible sigmoidoscopy rather than colonoscopy). Stabilizing patient prior to procedure is vital and it should be performed by expert endoscopist in a hospital-based settings. Informed consent with clear explanation of limited clinical data on fetomaternal safety is a prerequisite. Documentation of fetal heart sound pre- and postprocedure is mandatory with optional intraprocedure fetal heart rate monitoring. Pulse oximetry, oxygen supplementation, and electrocardiography monitoring is needed during procedure. It is important to perform EGD in left lateral position to avoid reflux and to avoid abdominal compression (during colonoscopy) and prone or supine position (to avoid compression of inferior vena cava by gravid uterus).

More prospective or case-control studies are required to establish safety of various endoscopic procedures during pregnancy. Most of the current evidence and recommendations are based on retrospective data (-Fig. 2). Randomized controlled studies are unlikely due to medico-legal issues. Ultrathin scopes and EUS guidance can help avoid radiation during ERCP with minimal anesthesia and pressure on graved uterus. Smaller, steerable video capsule endoscopes in future can help evaluate entire intestine noninvasively in a pregnant female as an alternative to invasive endoscopy.

\section{Authors' Contribution}

Conceptualization: P.P., MT; Literature review and writing original draft: P.P.; Illustrations: P.P.; Images: P.P.; Proof reading and critical review: M.T., D.N.R.; approving final manuscript: M.T., P.P., D.N.R. 


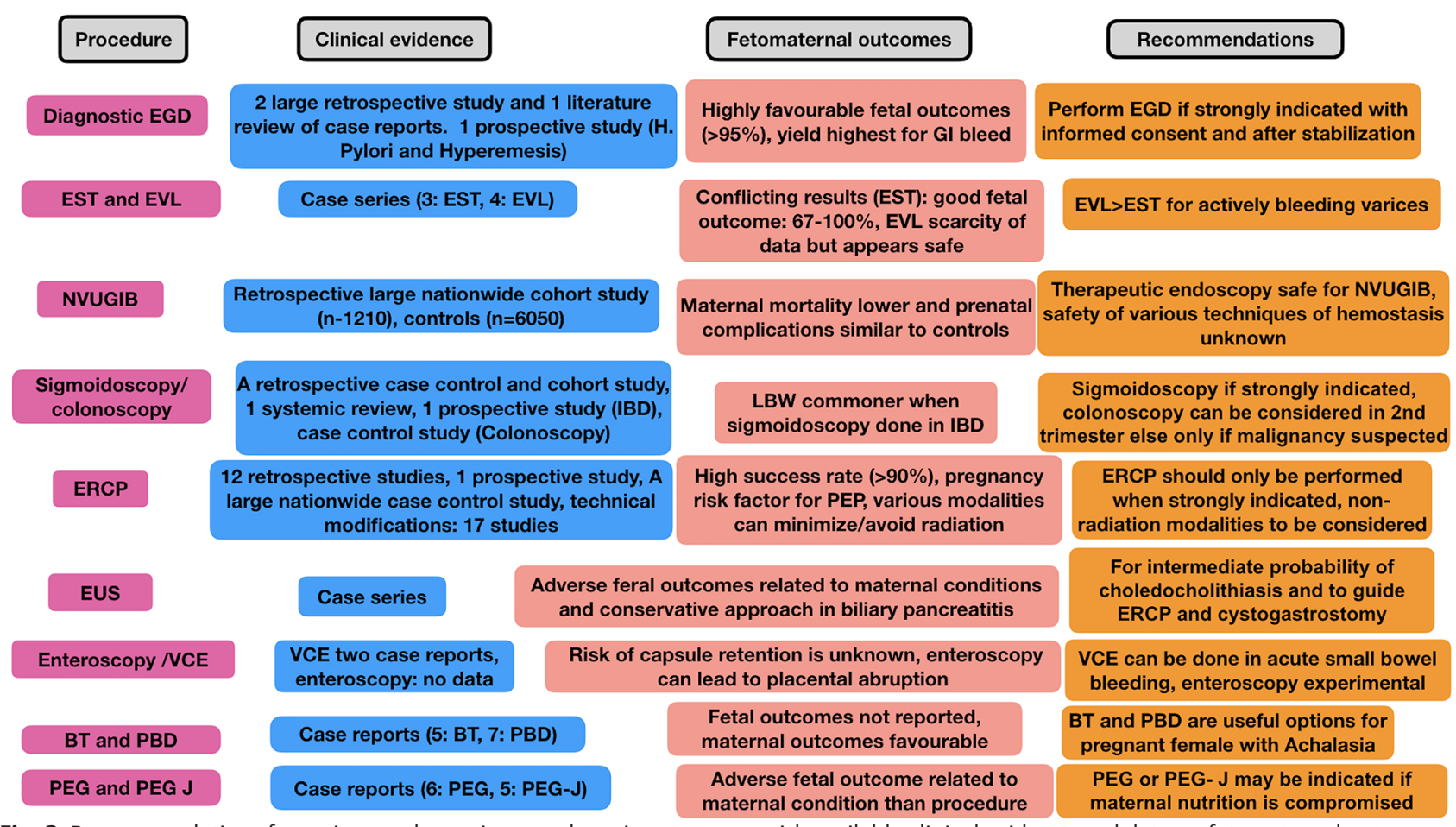

Fig. 2 Recommendations for various endoscopic procedures in pregnancy with available clinical evidence and data on fetomaternal outcomes. BT, botulinum toxin; EGD, esophagogastroduodenoscopy; EST, endoscopic sclerotherapy; ERCP, endoscopic retrograde cholangiopancreatography; EUS, endoscopic ultrasound; EVL, endoscopic variceal ligation; H. pylori, Helicobacter pylori; IBD, inflammatory bowel disease; LBW, low birth weight; NVUGIB, nonvariceal upper gastrointestinal bleed; PBD, pneumatic balloon dilation; PEG, percutaneous endoscopic gastrostomy; PEG-J, percutaneous endoscopic gastrojejunostomy; PEP, post-ERCP pancreatitis; VCE, video capsule endoscopy.

\section{Funding}

None.

\section{Conflict of Interest \\ None declared.}

\section{Acknowledgment}

None.

\section{References}

1 Cappell MS. Risks versus benefits of gastrointestinal endoscopy during pregnancy. Nat Rev Gastroenterol Hepatol 2011;8(11):610-634

2 de Lima A, Zelinkova Z, van der Woude CJ. A prospective study of the safety of lower gastrointestinal endoscopy during pregnancy in patients with inflammatory bowel disease. J Crohn's Colitis 2015;9(7):519-524

3 Bagis T, Gumurdulu Y, Kayaselcuk F, Yilmaz ES, Killicadag E, Tarim E. Endoscopy in hyperemesis gravidarum and Helicobacter pylori infection. Int J Gynaecol Obstet 2002;79(2):105-109

4 Nguyen GC, Dinani AM, Pivovarov K. Endoscopic management and outcomes of pregnant women hospitalized for nonvariceal upper GI bleeding: a nationwide analysis. Gastrointest Endosc 2010;72(5):954-959

5 Shergill AK, Ben-Menachem T, Chandrasekhara V; ASGE Standard of Practice Committee, et al; Guidelines for endoscopy in pregnant and lactating women. Gastrointest Endosc 2012;76(1):18-24 Erratum in: Gastrointest Endosc. 2013 May;77(5):833. PMID: 22579258
6 Cappell MS. Sedation and analgesia for gastrointestinal endoscopy during pregnancy. Gastrointest Endosc Clin N Am 2006;16(1):1-31

7 Cappell MS, Colon VJ, Sidhom OA. A study of eight medical centers of the safety and clinical efficacy of esophagogastroduodenoscopy in 83 pregnant females with follow-up of fetal outcome with comparison control groups. Am J Gastroenterol 1996;91(2):348-354

8 Debby A, Golan A, Sadan O, Glezerman M, Shirin H. Clinical utility of esophagogastroduodenoscopy in the management of recurrent and intractable vomiting in pregnancy. J Reprod Med 2008;53(5):347-351

9 Kochhar R, Kumar S, Goel RC, Sriram PV, Goenka MK, Singh K. Pregnancy and its outcome in patients with noncirrhotic portal hypertension. Dig Dis Sci 1999;44(7):1356-1361

10 Kochhar R, Goenka MK, Mehta SK. Endoscopic sclerotherapy during pregnancy. Am J Gastroenterol 1990;85(9):1132-1135

11 Aggarwal N, Sawhney H, Vasishta K, Dhiman RK, Chawla Y. Non-cirrhotic portal hypertension in pregnancy. Int J Gynaecol Obstet 2001;72(1):1-7

12 Mandal D, Dattaray C, Sarkar R, Mandal S, Choudhary A, Maity TK. Is pregnancy safe with extrahepatic portal vein obstruction? An analysis. Singapore Med J 2012;53(10):676-680

13 Keepanasseril A, Gupta A, Ramesh D, Kothandaraman K, Jeganathan YS, Maurya DK. Maternal-fetal outcome in pregnancies complicated with non-cirrhotic portal hypertension: experience from a tertiary centre in South India. Hepatol Int 2020;14(5):842-849

14 Dhiman RK, Biswas R, Aggarwal N, Sawhney H, Chawla Y. Management of variceal bleeding in pregnancy with endoscopic variceal ligation and $\mathrm{N}$-butyl-2-cyanoacrylate: report of three cases. Gastrointest Endosc 2000;51(1):91-93 
15 Vosko S, Cohen DL, Neeman O, Matalon S, Broide E, Shirin H. Achalasia during pregnancy: proposed management algorithm based on a thorough literature review. J Neurogastroenterol Motil 2021;27(1):8-18

16 Patel V, Nicar M, Emmett M, et al. Intestinal and renal effects of low-volume phosphate and sulfate cathartic solutions designed for cleansing the colon: pathophysiological studies in five normal subjects. Am J Gastroenterol 2009;104(4):953-965

17 Neri I, Blasi I, Castro P, Grandinetti G, Ricchi A, Facchinetti F. Polyethylene glycol electrolyte solution (Isocolan) for constipation during pregnancy: an observational open-label study. J Midwifery Womens Health 2004;49(4):355-358

18 Rottenstreich M, Mosmar K, Ehrlich Z, Kitroser E, Grisaru-Granovsky S. Flexible endoscopic decompression for treatment of sigmoid volvulus in pregnancy. Eur J Obstet Gynecol Reprod Biol 2019;242:184-185

19 Cappell MS, Colon VJ, Sidhom OA. A study at 10 medical centers of the safety and efficacy of 48 flexible sigmoidoscopies and 8 colonoscopies during pregnancy with follow-up of fetal outcome and with comparison to control groups. Dig Dis Sci 1996;41(12):2353-2361

20 Ko MS, Rudrapatna VA, Avila P, Mahadevan U. Safety of flexible sigmoidoscopy in pregnant patients with known or suspected inflammatory bowel disease. Dig Dis Sci 2020;65(10):2979-2985

21 Cappell MS, Fox SR, Gorrepati N. Safety and efficacy of colonoscopy during pregnancy: an analysis of pregnancy outcome in 20 patients. J Reprod Med 2010;55(3-4):115-123

22 Seubert DE, Puder KS, Goldmeier P, Gonik B. Colonoscopic release of the incarcerated gravid uterus. Obstet Gynecol 1999;94(5 Pt 1):792-794

23 De Lima A, Galjart B, Wisse PH, Bramer WM, van der Woude CJ. Does lower gastrointestinal endoscopy during pregnancy pose a risk for mother and child? - a systematic review. BMC Gastroenterol 2015;15:15

24 Brent RL. The effect of embryonic and fetal exposure to $\mathrm{x}$-ray, microwaves, and ultrasound: counseling the pregnant and nonpregnant patient about these risks. Semin Oncol 1989;16(5):347-368

25 Tham TC, Vandervoort J, Wong RC, et al. Safety of ERCP during pregnancy. Am J Gastroenterol 2003;98(2):308-311

26 Samara ET, Stratakis J, Enele Melono JM, Mouzas IA, Perisinakis K, Damilakis J. Therapeutic ERCP and pregnancy: is the radiation risk for the conceptus trivial? Gastrointest Endosc 2009;69(4):824-831

27 Friedel D, Stavropoulos S, Iqbal S, Cappell MS. Gastrointestinal endoscopy in the pregnant woman. World J Gastrointest Endosc 2014;6(5):156-167

28 Inamdar S, Berzin TM, Sejpal DV, et al. Pregnancy is a risk factor for pancreatitis after endoscopic retrograde cholangiopancreatography in a national cohort study. Clin Gastroenterol Hepatol 2016;14(1):107-114

29 Jamidar PA, Beck GJ, Hoffman BJ, et al. Endoscopic retrograde cholangiopancreatography in pregnancy. Am J Gastroenterol 1995;90(8):1263-1267

30 Farca A, Aguilar ME, Rodriguez G. de la Mora G, Arango L. Biliary stents as temporary treatment for choledocholithiasis in pregnant patients. Gastrointest Endosc 1997;46(1):99-101

31 Kahaleh M, Hartwell GD, Arseneau KO, et al. . Safety and efficacy of ERCP in pregnancy. Gastrointest Endosc 2004;60(2):287-292

32 Gupta R, Tandan M, Lakhtakia S, Santosh D, Rao GV, Reddy DN. Safety of therapeutic ERCP in pregnancy - an Indian experience. Indian J Gastroenterol 2005;24(4):161-163

33 Sharma SS, Maharshi S. Two stage endoscopic approach for management of choledocholithiasis during pregnancy. J Gastrointestin Liver Dis 2008;17(2):183-185
34 Shelton J, Linder JD, Rivera-Alsina ME, Tarnasky PR. Commitment, confirmation, and clearance: new techniques for nonradiation ERCP during pregnancy (with videos. Gastrointest Endosc 2008;67(2):364-368

35 Tang SJ, Mayo MJ, Rodriguez-Frias E, et al. . Safety and utility of ERCP during pregnancy. Gastrointest Endosc 2009;69(3 Pt 1) :453-461

36 Bani Hani MN, Bani-Hani KE, Rashdan A, AlWaqfi NR, Heis HA, Al-Manasra AR. Safety of endoscopic retrograde cholangiopancreatography during pregnancy. ANZ J Surg 2009;79(1-2):23-26

37 Daas AY, Agha A, Pinkas H, MamelJ, Brady PG. ERCP in pregnancy: is it safe? Gastroenterol Hepatol (N Y 2009;5(12):851-855

38 García-Cano J, Pérez-Miranda M, Pérez-Roldán F, et al. ERCP during pregnancy. Rev Esp Enferm Dig 2012;104(2):53-58

39 Zhou Y, Zhang X, Zhang X, et al. ERCP in acute cholangitis during third trimester of pregnancy. Hepatogastroenterology 2013;60(125):981-984

40 Ersoz G, Turan I, Tekin F, Ozutemiz O, Tekesin O. Nonradiation ERCP with endoscopic biliary sphincterotomy plus papillary balloon dilation for the treatment of choledocholithiasis during pregnancy. Surg Endosc 2016;30(1):222-228

41 Konduk BT, Bayraktar O. Efficacy and safety of endoscopic retrograde cholangiopancreatography in pregnancy: a high-volume study with long-term follow-up. Turk J Gastroenterol 2019;30(9):811-816

42 Akcakaya A, Ozkan OV, Okan I, Kocaman O, Sahin M. Endoscopic retrograde cholangiopancreatography during pregnancy without radiation. World J Gastroenterol 2009;15(29):3649-3652

43 Brewer Gutierrez OI, Godoy Brewer G, Zulli C, et al. . Multicenter experience with digital single-operator cholangioscopy in pregnant patients. Endosc Int Open 2021;9(2):E116-E121

44 Polydorou A, Karapanos K, Vezakis A, et al. A multimodal approach to acute biliary pancreatitis during pregnancy: a case series. Surg Laparosc Endosc Percutan Tech 2012;22(5): 429-432

45 Huang P, Zhang H, Zhang XF, Zhang X, Lü W, Fan Z. Comparison of endoscopic retrograde cholangiopancreatography performed without radiography and with ultrasound-guidance in the management of acute pancreaticobiliary disease in pregnant patients. Chin Med J (Engl 2013;126(1):46-50

46 Sethi S, Thosani N, Banerjee S. Radiation-free ERCP in pregnancy: a "Sound" approach to leaving no stone unturned. Dig Dis Sci 2015;60(9):2604-2607

47 Götzberger M, Pichler M, Gülberg V. Contrast-enhanced US-guided ERCP for treatment of common bile duct stones in pregnancy. Gastrointest Endosc 2012;76(5):1069-1070

48 Vohra S, Holt EW, Bhat YM, Kane S, Shah JN, Binmoeller KF. Successful single-session endosonography-based endoscopic retrograde cholangiopancreatography without fluoroscopy in pregnant patients with suspected choledocholithiasis: a case series. J Hepatobiliary Pancreat Sci 2014;21(2):93-97

49 Bar-Meir S, Rotmensch S. Investigation of obstructive jaundice by an ultra-thin-caliber endoscope: a new technique for potential use in pregnancy. Am J Obstet Gynecol 1984;150(8):1003-1004

50 Baillie J, Cairns SR, Putman WS, Cotton PB. Endoscopic management of choledocholithiasis during pregnancy. Surg Gynecol Obstet 1990;171(1):1-4

51 Cappell MS. The fetal safety and clinical efficacy of gastrointestinal endoscopy during pregnancy. Gastroenterol Clin North Am 2003;32(1):123-179

52 Baron TH, Schueler BA. Pregnancy and radiation exposure during therapeutic ERCP: time to put the baby to bed.? Gastrointest Endosc 2009;69(4):832-834 
53 Binmoeller KF, Katon RM. Needle knife papillotomy for an impacted common bile duct stone during pregnancy. Gastrointest Endosc 1990;36(6):607-609

54 Nesbitt TH, Kay HH, McCoy MC, Herbert WN. Endoscopic management of biliary disease during pregnancy. Obstet Gynecol 1996;87(5 Pt 2):806-809

55 Rahmin MG, Hitscherich R, Jacobson IM. ERCP for symptomatic choledocholithiasis in pregnancy. Am J Gastroenterol 1994;89(9):1601-1602

56 Girotra M, Jani N. Role of endoscopic ultrasound/SpyScope in diagnosis and treatment of choledocholithiasis in pregnancy. World J Gastroenterol 2010;16(28):3601-3602

57 Lee JJ, Lee SK, Kim SH, et al. Efficacy and safety of pancreatobiliary endoscopic procedures during pregnancy. Gut Liver 2015;9(5):672-678

58 Roumieu F, Ponchon T, Audra P, Gaucherand P. Acute pancreatitis in pregnancy: place of the different explorations (magnetic resonance cholangiopancreatography, endoscopic ultrasonography) and their therapeutic consequences. Eur J Obstet Gynecol Reprod Biol 2008;140(1):141-142
59 Chong VH. EUS complements ERCP during pregnancy. Gastrointest Endosc 2009;70(6):1285-1286, author reply 1286-1287

60 Magno-Pereira V, Moutinho-Ribeiro P, Macedo G. Demystifying endoscopic retrograde cholangiopancreatography (ERCP) during pregnancy. Eur J Obstet Gynecol Reprod Biol 2017;219:35-39

61 Hogan RB, Ahmad N, Hogan RB II, et al. Video capsule endoscopy detection of jejunal carcinoid in life-threatening hemorrhage, first trimester pregnancy. Gastrointest Endosc 2007; 66(1):205-207

62 Van Bodegraven AA, Böhmer CJ, Manoliu RA, et al. Gallbladder contents and fasting gallbladder volumes during and after pregnancy. Scand J Gastroenterol 1998;33(9):993-997

63 Aicart Ramos M, Volpato N, López San Román A. Retained capsule in Crohn's disease: what happens if i get pregnant? J Crohn's Colitis 2015;9(6):516

64 Ryan ME. Endoscopic management of a pancreatic pseudocyst during pregnancy. Gastrointest Endosc 1992;38(5):605-608

65 Gyokeres T,Topa L,Marton I, PapA.Endoscopic cystogastrostomy during pregnancy. Gastrointest Endosc 2001;53(4):516-518 